\title{
New Insights into Growth Hormone Receptor Function and Clinical Implications
}

\author{
A.M. Lichanska ${ }^{a}$ M.J. Waters ${ }^{b}$ \\ ${ }^{a}$ School of Dentistry, University of Queensland, Brisbane and ${ }^{\mathrm{b}}$ Institute for Molecular Bioscience and \\ School of Biomedical Science, St. Lucia, Australia
}

\section{Key Words}

Growth Hormone - Metabolism • Receptor activation • STAT5

\begin{abstract}
Although used as a therapeutic for 50 years, it is only recently that the application of molecular techniques has provided a basis for understanding growth hormone's $(\mathrm{GH})$ clinical actions. This article reviews progress in our current knowledge of the molecular mechanism of growth hormone $(\mathrm{GH})$ receptor activation based on a number of physicochemical techniques, and documents insights gained into the means used by the activated $\mathrm{GH}$ receptor to control the expression of genes regulating growth and metabolism. These findings are related to disorders of short stature, and the therapeutic consequences are summarized.
\end{abstract}

Copyright $\odot 2008$ S. Karger AG, Basel

\section{Introduction}

Growth hormone $(\mathrm{GH})$ is the main regulator of postnatal growth and an important metabolic regulator [1]. It acts through its receptor (GHR) to stimulate key signaling elements: JAK2, STAT5, PI3K, MAPK, STAT3 and PKC [2]. The stimulation of the receptor is pulsatile in males and continuous in females, reflecting the $\mathrm{GH}$ se- cretory pattern, particularly in Rodentia. This results in sexual dimorphism of liver transcripts and underpins sex-related metabolic differences [3].

Lack of GH or GHR in humans results in short stature, reduced muscle mass, increased fat storage, decreased cortical bone mineral density and decreased fertility in females [1]. The GH deficiency can be a result of genetic mutation, but it also is a normal consequence of aging. The levels of GH and its mediator, IGF-1, have been shown to decrease with age and $\mathrm{GH}$ replacement therapy has been shown to partially reverse the above-mentioned deficits [4].

\section{Receptor Structure and Mechanism of Action}

Because of its clinical potential, the interaction between $\mathrm{GH}$ and its receptor has been intensively studied, by Genentech in particular. Thus, the precise residues involved in the hormone-receptor interaction have been documented and their binding interaction energies quantified and mapped in space by X-ray crystallography [5]. The GHR was the first of the class 1 cytokine receptors to be cloned, and the first to have its crystal structure elucidated in complex with the ligand [6]. The structural information originating from these studies informed the study of other important members of the class 1 cytokine receptor family, including erythropoietin, prolactin,

\section{KARGER}

Fax +41613061234 E-Mail karger@karger.ch www.karger.com
(C) 2008 S. Karger AG, Base

0301-0163/08/0693-0138\$24.50/0

Accessible online at:

www.karger.com/hre
Prof. Michael Waters

Institute for Molecular Bioscience and School of Biomedical Science

St. Lucia 4072 (Australia)

Tel. +61 73346 2037, Fax +61 733462101

E-Mailm.waters@imb.ug.edu.au 
G-CSF, IL-3, IL-5 and IL-6, LIF, thrombopoietin and leptin. Of these, two closely related members of the family (erythropoietin and prolactin receptors) were, like the GHR, found to bind as homodimers to two different surfaces on the hormone, using similar binding sites on the two identical receptors. The main binding energy for $\mathrm{GH}$ binding to its receptor was shown to be hydrophobic energy derived from the burial of two tryptophan residues around the 4-helix bundle of GH. These tryptophans are each contributed by one of the two beta sandwich modules which comprise the extracellular part of the receptor. Their precise alignment is necessary for hormone binding, particularly for the first receptor which binds the hormone [5]. A key consequence of hormone binding to the two receptor molecules is that it facilitates binding together of the 'dimerization domain' within the lower sandwich module, which is necessary for signaling to occur [7].

The textbook version of GHR activation by the hormone $[6,8]$ states that the two receptor subunits are dimerized in the membrane by GH binding the first receptor with high affinity, then diffusing until a second receptor is contacted, resulting in receptor dimerization and productive alignment of the dimerization domains. This brings together JAK2 tyrosine kinases bound to the proline-rich box 1 sequence just below the cell membrane, and these activate each other by transphosphorylation in the kinase activation loop. Activated JAK2 then phosphorylates tyrosine residues in the cytoplasmic domain which act as recruitment points for $\mathrm{SH} 2$ and $\mathrm{PTB}$ binding modules contained in signaling proteins such as STAT5, which can themselves then be phosphorylated by JAK2, or used to recruit other signaling proteins downstream [2]. It is important to realize that the studies supporting hormone-dependent dimerization of the receptor were carried out with purified extracellular domain of the receptor, except for one study in cells showing activation by antibodies to the extracellular domain of the receptor, which used cells expressing a chimeric receptor with the GHR extracellular domain fused to the G-CSF receptor [8].

We have recently shown that the receptor exists as a constitutive dimer in the cell membrane in an inactive state [9]. This was demonstrated by FRET and BRET, spectral techniques which allow one to measure protein association in live cells and membranes. Co-association of differently epitope-tagged receptors can also be shown by co-immunoprecipitation, and was earlier reported with truncated receptors by a Dutch group [10]. Using a series of truncation mutants, it was established that the receptors are held together by their transmembrane domains (TMD) through relatively promiscuous leucine zipper-like interactions, with specificity in dimerization partner being conferred by the extracellular domain. It appears that constitutive dimerization with the wrong cytokine receptor partner is prevented by steric hindrance by other extracellular domains. We have further explored the TMD interaction using a bacterial TMD interaction assay, the ToxR assay, which has allowed us to ascribe functional roles for particular TMD residues. This data has been supported by determining which TMD residues are able to cross-link the receptor dimers together when converted to cysteine, and in the absence of hormone. These experiments define a face of the receptor TMD which interacts in the null state [Waters et al., unpubl. data].

If the receptor exists as a constitutive dimer in vivo, it must be activated by a conformational change induced by hormone binding. To discover what this might be we determined the crystal structure of the extracellular domain of the GHR in the absence of hormone and compared it to the published structures with hormone bound [9]. However, no major changes in conformation were apparent, although there was a twist of the upper domain with respect to the lower domain of around $8^{\circ}$. We looked again at the 2:1 structure of the receptor-hormone complex and noted that receptor 1 needs to be lifted and rotated with respect to receptor 2 when bound to the hormone. This is because the hormone binding sites are placed asymmetrically. We noted that in the putative 'unbound state', the dimerization domains cannot lock together because of steric and charge clashes, and that receptor 1 must be lifted and receptor 2 rotated for this to occur (see fig. 1 for a model of receptor activation).

If the hormone-induced conformational change involves relative rotation of receptor subunits, then rotating the subunits by other means may result in constitutively active receptors. Accordingly, we introduced alanine residues into the lower part of the TMD based on the understanding that introduction of an extra residue into an alpha helix will rotate the remainder of the helix by $100^{\circ}$ (3.6 residues/turn). We found constitutive activation of JAK2, STAT5 and cell growth with 4 insertions, which would rotate the helix by $400^{\circ}$ or $40^{\circ}$ past the start point [9]. To confirm this by different means, we substituted the extracellular domain of the GHR with a put 3 coiledcoil of known crystal structure, which facilitates relative movement of the TMD helices by removing helix residues at the put3-TMD fusion point, seriatum. Again we found a face of the receptor TMD which showed constitutive 
activity, which was around $40^{\circ}$ rotated from the inactive face. Thus only correct apposition of the two JAK2 molecules bound below the TMD can result in initiation of signaling [Waters and Pelekanos, unpubl. data].

The implication of these studies is that a GH agonist must correctly align the receptors, facilitating locking of the dimerization domains, and an antagonist will prevent this. Such an antagonist exists, being hGH with Gly 120 substituted by a large bulky residue (e.g. G120R or G120K). These will bind to the constitutive dimer, but cannot activate it as the bulky substituent at G120 prevents proper alignment of Trp 104 in the upper domain of the second receptor, so the receptors cannot realign to lock the dimerization domains together [8]. These GH antagonists, originally discovered by serendipity in the Kopchick lab, have progressed in a suitably modified form to become a highly effective therapeutic for acromegaly [11].

\section{Below the Membrane: GH Target Genes}

While the GH-GHR interaction is well studied, the regulation of gene expression by $\mathrm{GH}$ signaling in vivo has until recently been unexplored, especially with regard to the pathways regulating different actions of the hormone. In vitro, while numerous studies have mapped the cytoplasmic domains of the GHR used for controlling signaling pathways [2], only a few GH-regulated genes have been subjected to promoter analyses to define the signaling pathways responsible for regulation of their expression by GH. This has changed recently as a result of the application of microarray technology to identify GH target genes combined with genetically engineered rodent models [12]. As stature and metabolism can really be only studied in vivo, these studies used animal models to determine which genes are being regulated by GH.

The initial study used acute GH stimulation of GHdeficient dwarf rats [13], and identified hepatic genes immediately (1-6 h) induced by administration of GH. These included signal transducers (gp130, Stat3, p38Mapk), DNA repair proteins (Gadd45, Apen), receptor (Egfr) protease (Mt1-mmp) and metabolic regulators (Mct1, Igf1, Igfbp3, Fabp). This acute study did not offer an insight into long-term metabolic changes induced by $\mathrm{GH}$. Consequently, GH replacement therapy studies were performed in aged rats [14] or hypophysectomized rats $[15,16]$. However, while hypophysectomy eliminates GH secretion it also eliminates secretion of a number of other key hormones, such as TSH (thyroid-stimulating hor-

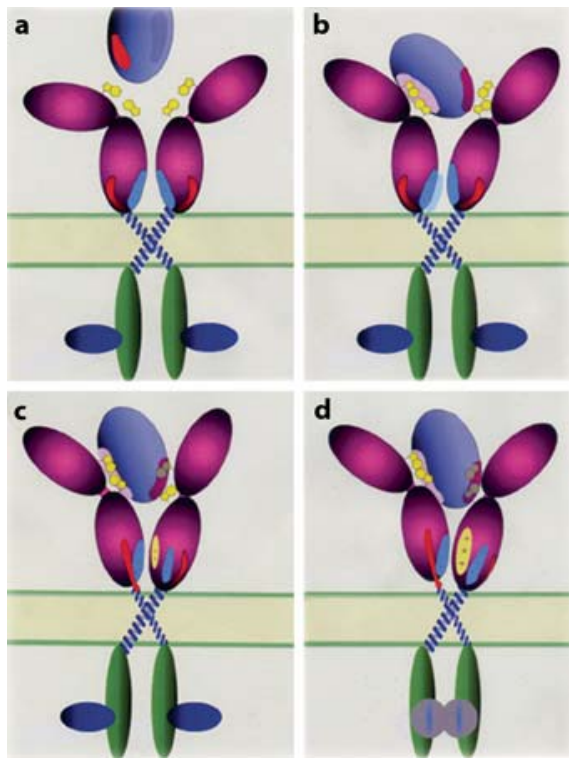

Fig. 1. Model for GHR activation. The hormone binds first to receptor 1 , then sits there until vibrational movement locates tryptophan 104 of receptor 2-adjacent binding site 2 of hormone. Binding to site 2 realigns the receptors such that receptor 1 is raised and rotated relative to receptor 2 because of the asymmetric placement of the receptor binding sites on the hormone. This realignment is transmitted through the TMD, aligning JAK2 kinases bound to box1 of the receptor, which facilitates their activation by transphosphorylation, so initiating the GH signaling cascades.

mone), ACTH (adrenocorticotropic hormone), FSH (follicle-stimulating hormone), LH (luteinizing hormone) and prolactin, thus making it difficult to dissect the $\mathrm{GH}$ specific effects. Further problems are created by the choice of the GH used (bovine vs. human) and mode of injection. Human GH activates prolactin receptors as well as GHR. Continuous administration of GH to aged or hypophysectomized rats tends to feminize the hepatic enzymes of male animals, since GH is normally secreted in large pulses in male rats [3]. A further limitation of these studies is that the replacement therapy has been relatively short, 1 week for hypophysectomized animals and 3 weeks for aged rats.

These limitations were overcome by generation of GHR-/- mouse [17], facilitating studies of altered growth and metabolism caused by the lack of receptor or partial GH resistance. Studies by Miller et al. [18] and Rowland et al. [12] identified dysregulated genes because of a lack of GH signaling. Moreover the gene expression profile in these animals has similarities with that of aging rats, implying that the $\mathrm{GH}$ deficiency in aging is similar to $\mathrm{GH}$ 
Table 1. Regulation of genes expressing metabolic enzymes in the liver of mice or rats

\begin{tabular}{|c|c|c|c|c|c|c|c|c|}
\hline Metabolic process & Gene & $\begin{array}{l}\text { GHR } \\
-/-[12]\end{array}$ & $\mathrm{Hx}[15]$ & $\begin{array}{l}\text { Old vs. } \\
\text { young [14] }\end{array}$ & $\begin{array}{l}\mathrm{Hx}+\mathrm{GH} \\
{[15]}\end{array}$ & $\begin{array}{l}\text { Males + GH } \\
\text { vs. males }{ }^{\mathrm{a}}[32]\end{array}$ & $\begin{array}{l}\text { Age }+ \\
\text { GH [14] }\end{array}$ & $\begin{array}{l}\text { bGH Tg } \\
{[33]}\end{array}$ \\
\hline $\begin{array}{l}\text { Carbohydrate/ } \\
\text { energy metabolism }\end{array}$ & $\begin{array}{l}\text { Glucose-6-phosphate catalytic subunit } \\
\text { Gapdh } \\
\text { Pyruvate dehydrogenase } \\
\text { Fumarate hydratase } \\
\text { Aldolase } \\
\text { Fructose-1,6-bisphosphatase } \\
\text { Transkletolase } \\
\text { Glucose-6-phosphate dehydrogenase }\end{array}$ & $\begin{array}{l}\text { down } \\
\text { n.c. } \\
\text { up } \\
\text { up } \\
\text { n.c. } \\
\text { up } \\
\text { n.c. } \\
\text { n.c. }\end{array}$ & $\begin{array}{l}\text { down } \\
\text { down } \\
\text { down }\end{array}$ & $\begin{array}{l}\text { down } \\
\text { up } \\
\text { up } \\
\text { up } \\
\text { up } \\
\text { up } \\
\text { up }\end{array}$ & up & up & $\begin{array}{l}\text { up } \\
\text { n.c. } \\
\text { n.c. } \\
\text { n.c. } \\
\text { n.c. } \\
\text { down } \\
\text { down }\end{array}$ & up \\
\hline Fat metabolism & $\begin{array}{l}\text { 2,4-Dienoyl CoA reductase } 1 \\
\text { Stearyl-CoA desaturase } \\
\text { CD36 (fatty acid transporter) } \\
\text { Cpt1 } \\
\text { Fatty acid CoA ligase long chain } \\
\text { Fatty acid synthase } \\
\text { Enoyl CoA hydratase } \\
\text { 3-Ketoacyl-CoA thiolase } \\
\text { Carnitine O-octanoyltransferase (Crot) } \\
\text { Niemann-Pick C1 protein }\end{array}$ & $\begin{array}{l}\text { up } \\
\text { down } \\
\text { up } \\
\text { n.c. } \\
\text { n.c. } \\
\text { up } \\
\text { up } \\
\text { n.a. } \\
\text { up }\end{array}$ & $\begin{array}{l}\text { up } \\
\text { down }\end{array}$ & $\begin{array}{l}\text { n.c. } \\
\text { up } \\
\text { up.c. } \\
\text { up } \\
\text { up } \\
\text { up } \\
\text { up } \\
\text { down }\end{array}$ & $\begin{array}{l}\text { down } \\
\text { up } \\
\text { up }\end{array}$ & $\begin{array}{l}\text { up } \\
\text { down } \\
\text { down } \\
\text { up }\end{array}$ & $\begin{array}{l}\text { up } \\
\text { down } \\
\text { down } \\
\text { up } \\
\text { down } \\
\text { down } \\
\text { down } \\
\text { down } \\
\text { up }\end{array}$ & $\begin{array}{l}\text { down } \\
\text { up } \\
\text { down } \\
\text { down } \\
\text { down } \\
\text { down }\end{array}$ \\
\hline $\begin{array}{l}\text { Intermediary } \\
\text { metabolism }\end{array}$ & $\begin{array}{l}\text { Iduronidase, alpha-L- } \\
\text { Lactate dehydrogenase } \\
\text { Glutamic pyruvic transaminase } 1 \\
\text { Farnesyl diphosphate synthase } \\
\text { Glutamate dehydrogenase } 1 \\
\text { Xanthine dehydrogenase }\end{array}$ & $\begin{array}{l}\text { n.a. } \\
\text { n.c. } \\
\text { n.a. } \\
\text { n.c. } \\
\text { n.c. } \\
\text { n.c. }\end{array}$ & $\begin{array}{l}\text { up } \\
\text { down } \\
\text { up } \\
\text { down } \\
\text { down }\end{array}$ & $\begin{array}{l}\text { n.c. } \\
\text { down } \\
\text { n.c. }\end{array}$ & $\begin{array}{l}\text { down } \\
\text { up } \\
\text { down }\end{array}$ & up & $\begin{array}{l}\text { n.c. } \\
\text { n.c. } \\
\text { up } \\
\text { up }\end{array}$ & \\
\hline Transcription factors & PPARa & & up & up & down & & down & down \\
\hline
\end{tabular}

$\mathrm{Hx}=$ Hypophysectomized rats; $\mathrm{Tg}=$ mice overexpressing GH; n.a. = not assayed, n.c. = not changed

${ }^{a}$ Male rats treated with continuous GH injections.

deficiency. The linking of different signaling pathways to metabolic responses was possible after the generation of the GHR KI mice [12]. In this study the mutations in the ICD of the GHR facilitated the identification of target genes for particular signaling pathways and their effects on metabolism in the long term. Mice were created with reduced levels of GH-dependent STAT5 signaling [30\% of wild type (WT) in mutant 569] or no GH-dependent STAT5 signaling (mutant 391) in response to GH stimulation. However, these mice displayed normal JAK2 activation and ERK (MAPK) stimulation with GH administration. Comparison of the mutant 391 to GHR-/- mice indicated that around 200 genes are regulated by signaling from the proximal part of the receptor, where JAK2 and ERK signaling originates.

Transcripts for metabolic enzymes, particularly involving fat metabolism and energy metabolism, are significantly altered by GH in the liver [12, 14-16] (table 1).
The general features of all these studies are low fold changes (majority up to 2.5 -fold), with steroid and drugmetabolizing enzymes being the most changed (above 2.5 -fold). GH injection of aged rats restored the male pattern of CYPs, induced expression of glutathione transferases, reversed the decrease in glucose-6-phosphatase expression and changed the expression of enzymes of fat and steroid metabolism. Although continuous administration of GH in hypophysectomized male rats feminizes their transcript expression to some extent, the gene expression profile still differs from the female (e.g. glucose6-phosphate dehydrogenase, CD36, Fasn, Acs5, Scd1, G6pc), possibly because of incomplete replacement of other hormones. In general, hepatic lipid oxidation is increased by pulsatile GH (as in the male) and synthesis by continuous $\mathrm{GH}$, as in the female. 
Fig. 2. Postnatal growth of GHR-engineered mice.

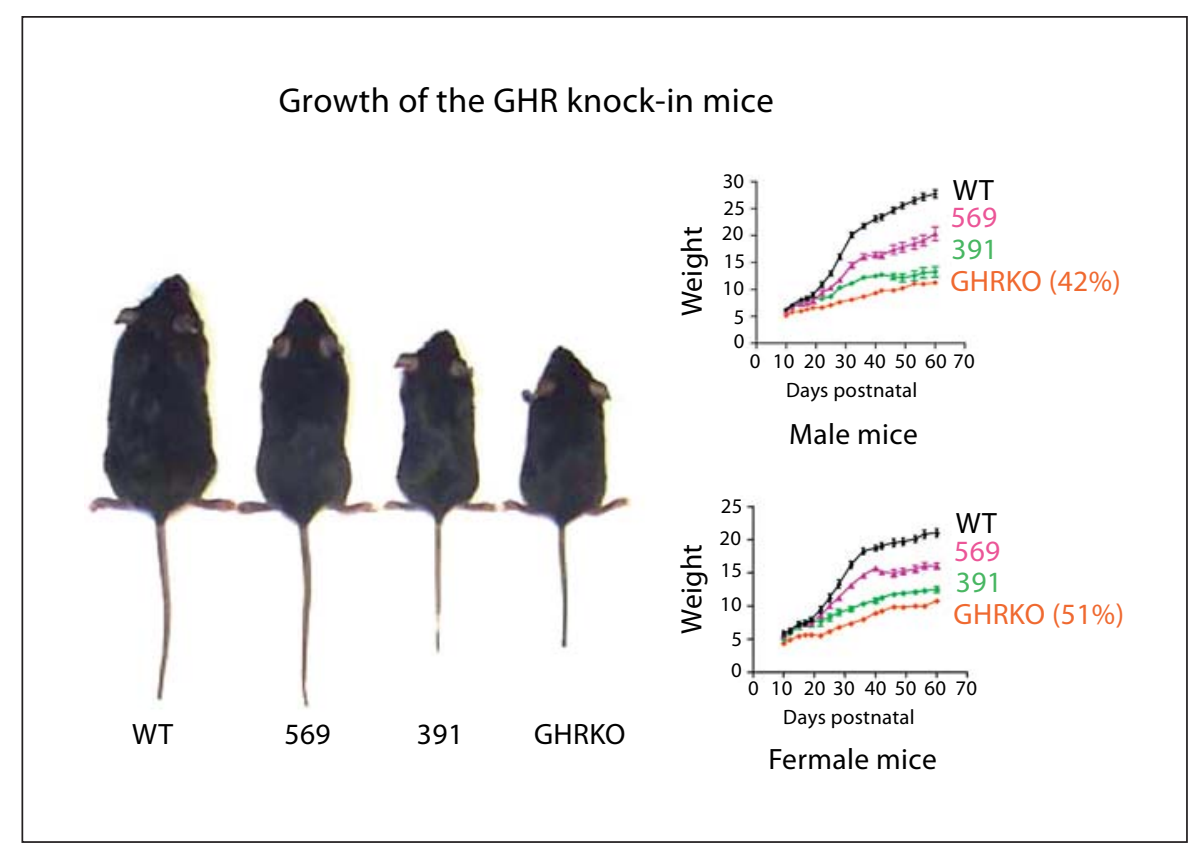

\section{Dissecting Signaling Pathways of the Receptor, the Role of STAT5}

STAT transcription factors are regarded as the most important mediators of GH actions [2]. STAT1, 3, 5A and $5 \mathrm{~B}$ are phosphorylated in response to $\mathrm{GH}$ in vitro and in vivo by JAK2, but the activation of STAT5 also requires binding of STAT5 to phosphorylated tyrosines of the intracellular domain of the receptor. Transgenic models for STATs have shown that STAT1 has no effects on growth; however, its role in other actions of GH was not investigated, STAT3-/- is embryonic lethal, STAT5a had no effect on body size, while STAT5b resulted in decreased size in males (25\% smaller than WT littermates) but not in females $[19,20]$. Double STAT5a/b-/- mice are further decreased in size in both sexes [21]. Mutations in the ICD of the GHR which prevent STAT5 activation decrease postnatal growth of both sexes by up to $50 \%$ in mutant 391 , comparable to the $55 \%$ decrease in GHR-/- mice [12] (fig. 2-4). This decrease in postnatal growth occurs because STAT5b regulates expression of $I g f-1$, as evident in recent promoter analysis studies [22] as well as Igfbp3 and Igfals [12], which stabilize IGF-1 in circulation. These results are clinically relevant as a lack of STAT5b signaling in humans results in severe short stature, as recently evident in several probands harboring mutations in Stat $5 b$ [23]. Curiously, while postnatal growth is decreased by a lack of STAT5b in mice, the extent of loss is not the same as seen in GHR-/- mice or 391 mutants unable to activate STAT5b $[12,20]$. This discordance led to identify another transcription factor (HNF3 $\beta$ ) which is decreased in GHR-/- mice and mutant 391 mice, and which activates Igf-1, which could account for the lesser severity of growth deficit in the Stat5-/- mice [12] (fig. 2-4).

Functional effects of STAT5 on hepatic metabolism can be divided into two groups: genes regulated by sexually dimorphic signaling and genes requiring STAT5 for expression independently of the sex. The sexual dimorphism of gene expression in the liver, regulated by pulsatile GH secretion, is generated by STAT5b actions [24,25]. In particular cytochromes P450 (CYP) are differentially expressed between the sexes, notably Cyp2c11, 2c12, 2a2, $2 \mathrm{~d} 9,3 \mathrm{a} 2,3 \mathrm{a} 4$, and $3 \mathrm{a} 10$, and major urinary proteins. In GHR-/-, STAT5-/- or GHR mutant males their expression is aberrant and the levels of expression are similar to WT females, while the levels of female-specific transcripts have levels intermediate between WT males and females.

In addition to mediating of sexually dimorphic gene expression, STAT5 has been associated with regulation of metabolic gene expression, especially in relation to fat metabolism. In vitro studies have shown STAT5 to be a mediator of adipocyte differentiation [26], and in vivo lack of STAT5a or GHR results in decreased weight of epididymal fat pads in young males [21, 26]. However, mature mice lacking GHR or the ability to generate active 
Fig. 3. Signaling domains in GHR-engineered mice (a), and immunoblots showing ability of $\mathrm{GH}$ injection to activate JAK2 and ERK, but not STAT5 in liver of 19-dayold mice of 391 truncated mice [from 12].

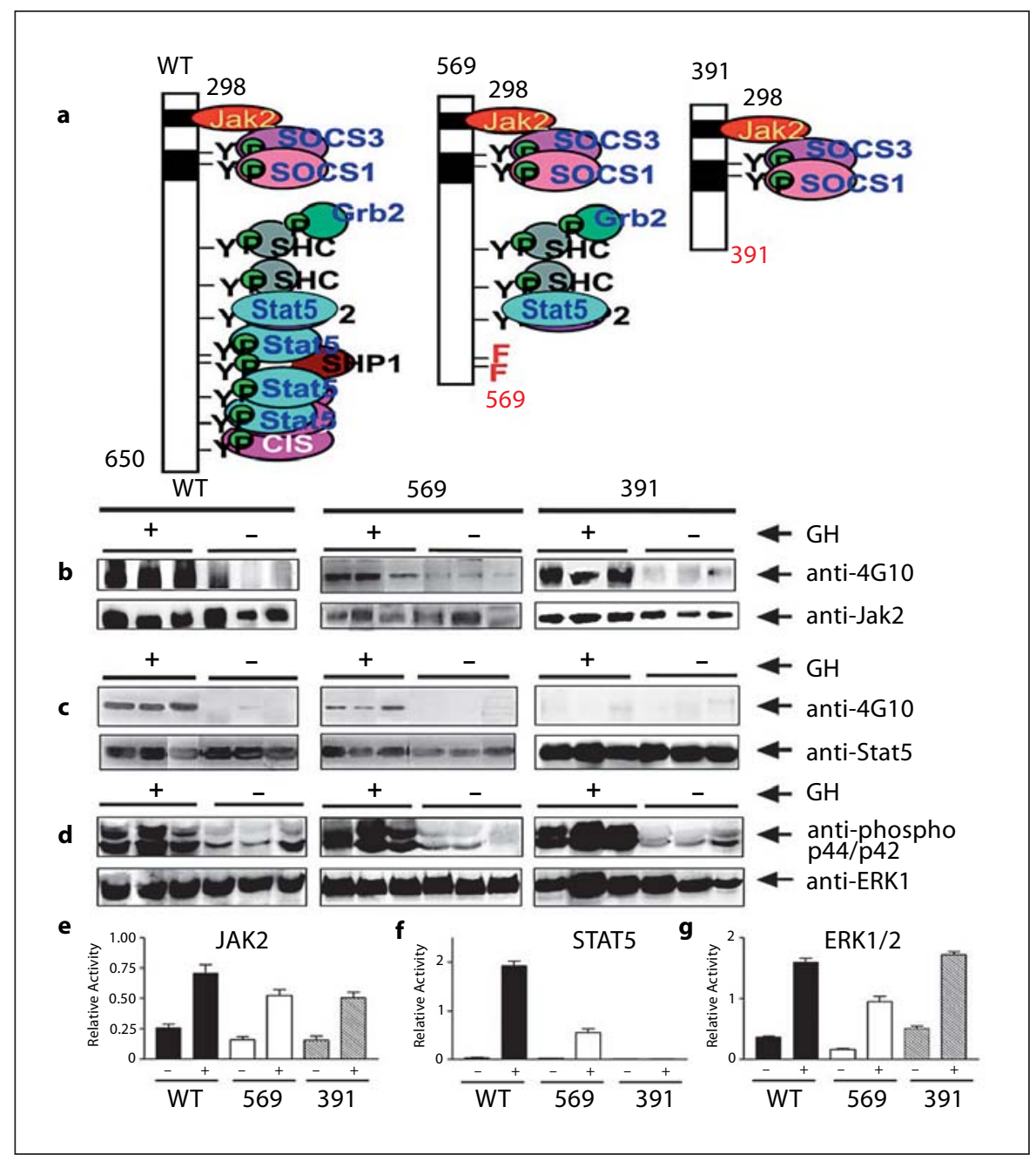

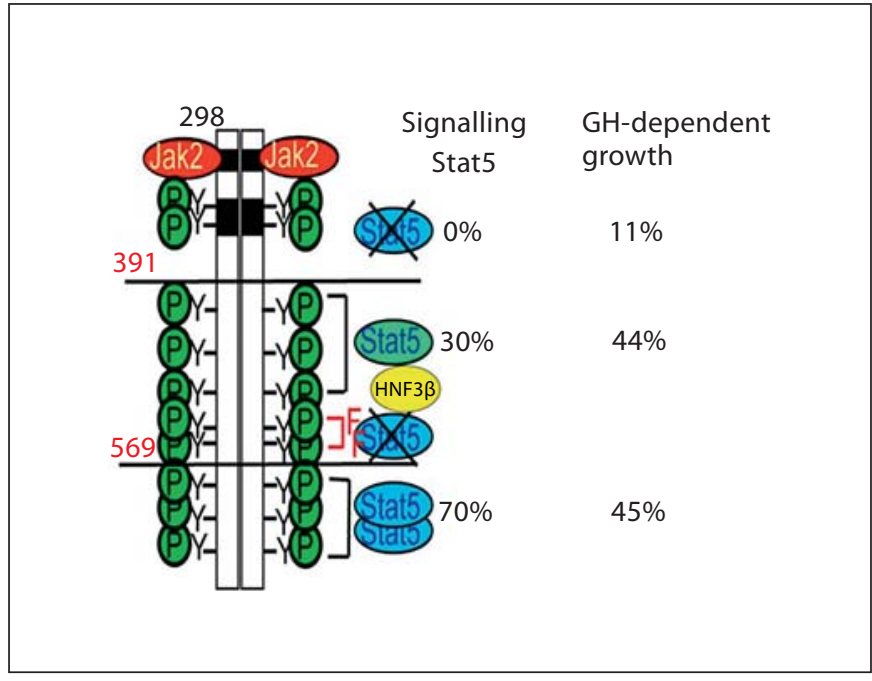

Fig. 4. Contributions of GHR signaling domains to postnatal growth [from 12].

GHR Function and Clinical Implications

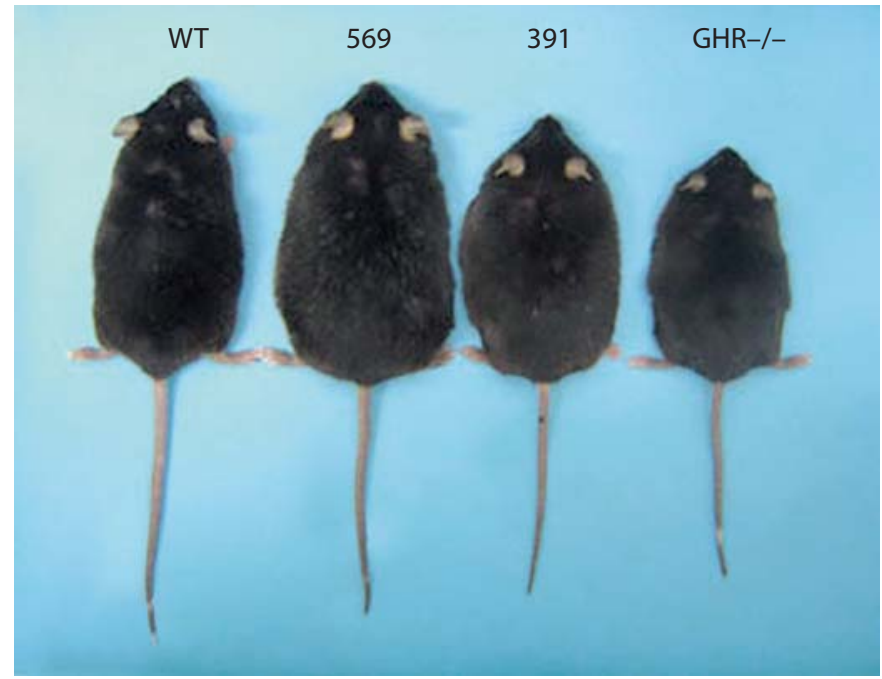

Fig. 5. Adiposity in male GHR-engineered mice at 12 months of age.

Horm Res 2008;69:138-145 
STAT5 become quite obese, particularly from accumulation of subcutaneous fat [27] (fig. 5). This may be a consequence of the inability to generate a lipolytic response by $\mathrm{GH}$, since fat pads from Stat $5 a / b-/-$ mice show no lipolytic response to $\mathrm{GH}$ in vitro [28]. Moreover, fatty acid synthase (Fasn) expression is repressed by STAT5a via a response element in its promoter [29]. In relation to the well-known insulin antagonistic actions of GH, the 569 mutant mice but not the 391 mutant or GHR-/- mice display insulin resistance. This is concordant with involvement of STAT5 in this phenomenon, since 569 mutants have highly elevated plasma GH (due to low plasma IGF-1) and are able to generate $30 \%$ of peak STAT5 activation in response to $\mathrm{GH}$ administration.

\section{Clinical Implications}

\section{Short Stature}

The recent studies showing that STAT5 activation of the IGF-1 promoter is necessary for its expression have provided a rational basis for the use of this mediator of $\mathrm{GH}$ action to promote statural growth in patients with $\mathrm{GH}$ resistance based on failure of $\mathrm{GH}$ to activate receptor signaling. The failure may be the result of a mutation in the receptor of which there are now over 50 identified, almost all in the extracellular domain. Alternatively, it may be a result of mutation in downstream signaling elements such as STAT5 [23]. There are additional pathways which contribute to postnatal growth however, since crosses of IGF-1-/- mice with GHR-/- mice are smaller than IGF1-/- mice alone [30], and these pathways may involve cytokine signaling pathways other than JAK2/ STAT5 signaling. This provides an explanation why IGF-1 replacement is not as effective as GH in promoting postnatal growth in the clinical setting.

\section{Acromegaly, Diabetic Nephropathy and Cancer:}

Targets for GH Antagonists

The G120-substituted hGH antagonist alluded to above was developed as a therapeutic by Genentech by increasing its binding affinity for the first receptor using phage display technology and by increasing its circulating half-life with substitution of polyethylene glycol chains. Pegvisomant or Trovert has been shown to be efficacious in the treatment of acromegaly, and superior to somatostatin in terms of IGF-1 response. Studies in experimental animals have shown promising results in the control of diabetic nephropathy and a variety of cancers, and clinical studies in this area are certainly war- ranted [11]. We have recently reported that an alternative to pegvisomant, modified antisense oligonucleotides to the GHR, is able to lower serum IGF-1 in mice to similar levels as pegvisomant, and inhibits long-term body weight gain in mice [31]. These remain to be clinically tested.

\section{GH Response Markers}

Currently, serum IGF-1 and to a lesser extent IGFBP3 are common short-term markers for $\mathrm{GH}$ responsiveness in patients with short stature. It is expected that a variety of other markers will eventuate from the microarray analyses of hepatic GH-responsive genes, as well as proteomic approaches to serum analysis. Recently, we have used NMR analysis of urine from mice harboring mutations to the GHR, and have identified changes in particular metabolites corresponding to altered transcript expression by microarray. These metabolites may provide another avenue for monitoring GH responsiveness.

\section{Obesity}

Given the extreme obesity of GHR-deficient mice, and the use of GH in the livestock industry to produce leaner pigs with decreased subcutaneous fat depots and increased muscle, one would have hoped the application of GH to human obesity would have been more successful. There is currently progress in elucidating the molecular targets of GH action in obesity, and these insights may yet provide a rational treatment for obesity.

\section{Conclusions}

Modern molecular approaches have provided new understanding of the basis for the long-known actions of $\mathrm{GH}$ in promoting postnatal growth and altering body composition. They have also provided new therapies and diagnostics of considerable promise. However, a specific, orally active small GH agonist able to activate the receptor by inducing the appropriate alignment of receptor subunits still remains a difficult challenge. 


\section{References}

1 Bengtsson BA: Growth Hormone. Norwell, Kluwer Academic Publishers, 1999.

2 Herrington J, Carter-Su C: Signaling pathways activated by the $\mathrm{GH}$ receptor. Trends Endocrinol Metab 2001;12:252-257.

-3 Shapiro BH, Agrawal AK, Pampori NA: Gender differences in drug metabolism regulated by GH secretion. Int J Biochem Cell Biol 1995;27:9-20.

-4 Rudman D, Feller AG, Nagraj HS, Gergans GA, et al: Effects of hGH in men over 60 years old. N Engl J Med 1990;323:1-6.

5 Wells JA: Binding in the GH receptor complex. Proc Natl Acad Sci USA 1996;93:1-6.

6 Waters MJ: The growth hormone receptor; in Kostyo JL, HM Goodman (eds): Handbook of Physiology. London, Oxford Press, vol 5, sect 7, chap 13, pp 397-444.

7 Chen CM, Brinkworth R, Waters MJ: The role of receptor dimerization domain residues in GH signalling. J Biol Chem 1997;272: 5133-5140.

-8 Fuh G, Cunningham BC, Fukunaga R, Nagata S, Goeddel DV, Wells JA: Rational design of potent antagonists to the human GH receptor. Science 1992;256:1677-1680.

-9 Brown RJ, Adams JJ, Pelekanos RA, Wan Y, McKinstry WJ, Palethorpe K, Seeber RM, Monks TA, Eidne KA, Parker MW, Waters MJ: Model for GH receptor activation based on subunit rotation within a constitutive dimer. Nat Struct Mol Biol 2005;12:814-821.

10 Gent J, van Kerkhof P, Roza M, Bu G, Strous GJ: Ligand-independent GH receptor dimerization occurs in the endoplasmic reticulum and is required for ubiquitin system-dependent endocytosis. Proc Natl Acad Sci USA 2002;99:9858-9863.

-11 Muller F, Kopchick JJ, Flyvbjerg A, van Der Ley AJ: Clinical review 166: GH receptor antagonists. J Clin Endocrinol Metab 2004;89: 1503-1511.

12 Rowland JE, Lichanska AM, Kerr LM, White M, D’Aniello EM, Mahler SL, Brown RJ, Teasdale R, Noakes PG, Waters MJ: In vivo analysis of GH receptor signalling domains and their associated transcripts. Mol Cell Biol 2005;25:66-77.

13 Thompson BJL, Shang CA, Waters MJ: Identification of genes induced by $\mathrm{GH}$ in rat liver using cDNA arrays. Endocrinology 2000; 141:4321-4324.
14 Tollet-Egnell P, Flores-MoralesA, Stahlberg N, Malek RL, Lee N, Norstedt G: Gene expression profile of the aging process in rat liver: normalizing effects of GH replacement. Mol Endocrinol 2001;15:308-318.

15 Flores-Morales A, Stahlberg N, Tollet-Egnell $>_{2}$ P, Lundeberg J, Malek RL, Quackenbush J, Lee NH, Norstedt G: Microarray analysis of the in vivo effects of hypophysectomy and $\mathrm{GH}$ treatment on gene expression in the rat. Endocrinology 2001;142:3163-3176.

16 Gardmo C, Swerdlow H, Mode A: GH regulation of rat liver gene expression assessed by SSH and microarray. Mol Cell Endocrinol 2002;190:125-133.

$>17$ Zhou Y, Xu BC, Maheshwari HG, He L, Reed M, Lozykowski M, Okada S, Cataldo L, Coschigano K, Wagner TE, Baumann G, Kopchick JJ: A mammalian model for Laron syndrome produced by targeted disruption of the mouse GH receptor. Proc Natl Acad Sci USA 1997;94:13215-13220.

18 Miller RA, Chang Y, Galecki AT, Al-Regaiey K, Kopchick JJ, Bartke A: Gene expression patterns in calorically restricted mice: partial overlap with long-lived mutant mice. Mol Endocrinol 2002;16:2657-2666.

19 Levy DE: Physiological significance of STAT proteins: investigations through gene disruption in vivo. Cell Mol Life Sci 1999;55: 1559-1567.

-20 Udy GB, Towers RP, Snell RG, Wilkins RJ, Park SH, Ram PA, Waxman DJ, Davey HW: Requirement of STAT5b for sexual dimorphism of body growth rates and liver gene expression. Proc Natl Acad Sci USA 1997;94: 7239-7244.

-21 Teglund S, McKay C, Schuetz E, van Deursen JM, Stravopodis D, Wang D, Brown M, Bodner S, Grosveld G, Ihle JN: Stat5a and Stat5b have essential and nonessential, or redundant, roles in cytokine responses. Cell 1998; 93:841-850.

22 Woelfle J, Chia DJ, Rotwein P: Mechanisms of $\mathrm{GH}$ action. Identification of conserved Stat 5 binding sites that mediate GH-induced IGF-1 gene activation. J Biol Chem 2003;278: 51261-51266.

23 Kofoed EM, Hwa V, Little B, Woods KA, Buckway CK, Tsubaki J, Pratt KL, Bezrodnik L, Jasper H, Tepper A, Heinrich JJ, Rosenfeld RG: GH insensitivity associated with a STAT5b mutation. N Engl J Med 2003;349: 1139-1147.
24 Tannenbaum GS, Choi HK, Gurd W, Waxman DJ: Temporal relationship between the sexually dimorphic spontaneous GH secretory profiles and hepatic STAT5 activity. Endocrinology 2001;142:4599-4606.

25 Clodfelter KH, Holloway MG, Hodor P, Park SH, Ray WJ, Waxman DJ: Sex-dependent liver gene expression is extensive and largely dependent upon STAT5b: STAT5b-dependent activation of male genes and repression of female genes revealed by microarray. Mol Endocrinol 2006;20:1333-1351.

26 Shang CA, Waters MJ: Constitutively active Stat 5 can replace the requirement for $\mathrm{GH}$ in adipogenesis of 3T3-F442A. Mol Endocrinol 2003;17:2494-2508.

27 Berryman DE, List EO, Kohn DT, Coschigano KT, Seeley RJ, Kopchick JJ: Effect of GH on susceptibility to diet-induced obesity. Endocrinology 2006;147:2801-2808.

28 Fain JN, Ihle JH, Bahouth SW: Stimulation of lipolysis but not of leptin release by GH is abolished in adipose tissue from Stat $5 \mathrm{a} / \mathrm{b}$ knockout mice. Biochem Biophys Res Commun 1999;263:201-205.

29 Hogan JC, Stephens JM: The regulation of fatty acid synthase by STAT5A. Diabetes 2005;54:1968-1975.

30 Lupu F, Terwilliger JD, Lee K, Segre GV, Efstratiadis A: Roles of GH and IGF-1 in mouse postnatal growth. Dev Biol 2001;229:141162.

31 Tachas G, Lofthouse S, Wraight CJ, Baker BF, Sioufi NB, Jarres RA, Berdeja A, Rao AM, Kerr LM, D'Aniello EM, Waters MJ: A GH receptor antisense oligonucleotide inhibits hepatic GH receptor expression, IGF-1 production and body weight gain in normal mice. J Endocrinol 2006;189:147-154.

32 Stahlberg N, Merino R, Hernandez LH, Fernandez-Perez L, Sandelin A, Egstrom P, Tollett-Egnell P, Lenhard B, Flores-Morales A: Exploring hepatic hormone actions using a compilation of gene expression profiles. BMC Physiol 2005;5:8.

33 Olsson B, Bohlooly M, Brusehed O, Isaksson OGP, Ahren B, Olofsson S-O, Oscarsson J, Tornell J: Bovine GH-transgenic mice have major alterations in hepatic expression of metabolic genes. Am J Physiol Endocrinol Metab 2003;285:504-511. 